\title{
PENGARUH FREKUENSI PENDIDIKAN KESEHATAN TERHADAP PRILAKU KONTROL (MONITORING) KADAR GULA DARAH PADA LANSIA DENGAN RIWAYAT PENYAKIT DIABETES MELLITUS
}

\author{
*Sunardi, *Toto Subiakto
}

\begin{abstract}
Abstrak
Saat ini 6,3 juta (19\%) dari seluruh orang yang berusia $>65$ tahun memiliki diabetes mellitus. (Black \& Hawks, 2014). Manifestasi klinis meyakinkan adanya diabetes mellitus, tetapi uji laboratorium kadar gula darah diperlukan untuk menegakan diagnostik pasti, pemeriksaan kadar gula darah secara teratur dan terencana dapat mendeteksi adanya kelainan lebih lanjut. Pendidikan kesehatan merupakan salah satu cara dalam menentukan keberhasilan manajemen diabetes mellitus. Fenomena yang terjadi dan menjadi masalah penelitian ini adalah apakah benar bahwa prilaku kontrol(monitoring) kadar gula darah seseorang yang mengalami diabetes mellitus dapat dipengaruhi oleh banyaknya frekwensi pendidikan kesehatan yang diterimannya. Penelitian ini bertujuan untuk mengidentifikasi Pengaruh frekuensi pendidikan kesehatan terhadap prilaku kontrol (monitoring) kadar gula darah pada lansia yang memiliki penyakit diabetes mellitus. Desain Penelitian adalah deskriptif korelasi dengan pendekatan cross sectional. Penelitian dilakukan di wilayah Puskesmas kecamatan Neglasari Kota Tangerang, pengambilan sampel dilaksanakan bulan Juni-September 2015 terhadap lansia dengan riwayat diabetes mellitus yang berobat/kontrol kepuskesmas. Hasil penelitian dari 60 responden, menunjukkan ada hubungan yang siknifikan antara frekwensi pendidikan kesehatan dengan prilaku kontrol (Monitoring) kadar gula darah pada lansia yang mengalami diabetes mellitus, dengan nilai $\mathrm{p}=0,001(\alpha=0,05)$. Hal ini berarti semakin banyak pendidikan kesehatan yang diterima lansia, maka semakin sering lansia berprilaku control (monitoring) kadar gula darahnya.
\end{abstract}

Kata kunci : Diabetes Mellitus Lansia, Kontrol Gula darah, Frekuensi pendidikan Kesehatan

*Poltekkes Kemenkes Banten 


\title{
INFLUENCE OF HEALTH EDUCATION TOWARDS BEHAVIOUR OF FREQUENCY CONTROL (MONITORING) BLOOD SUGAR LEVELS IN THE ELDERLY WITH A HISTORY OF DISEASE DIABETES MELLITUS
}

\author{
*Sunardi, *Toto Subiakto
}

\begin{abstract}
Currently 6.3 million (19\%) of all 65-year-old > has diabetes mellitus. (Black \& Hawks,2014). Clinical manifestation of reassuring the presence of diabetes mellitus, but laboratory testing of blood sugar levels is required for erecting a definite diagnostic, examination of the blood sugar levels regularly and wellplanned can detect any abnormalities. Health education is one way in determining the success of the management of diabetes mellitus. The phenomenon occurs and becomes a problem this research is whether it is true that the behavior monitoring blood sugar levels a person experiencing diabetes mellitus can be influenced by a multitude of frequencies diterimannya health education. This research aims to identify the influence of frequency of health education towards behaviour monitoring blood sugar levels on the elderly who have diabetes mellitus. Design research is a descriptive cross sectional approach to correlation. Research done in the area of public health centers Neglasari Tangerang, sampling was carried out in June-September 2015 against the elderly with a history of diabetes mellitus that is visited to public health center. The research results of 60 respondents, showed no relationship between the significance of health education behavior with frequency Monitoring blood sugar levels on the elderly who suffered diabetes mellitus, with a value of $\quad p=0.001(\alpha=0.05)$. This means more and more health education received the elderly, the elderly often behave monitoring his blood sugar level.
\end{abstract}

Keywords : Elderly diabetes mellitus, blood sugar monitoring, frequency of health education 


\section{Pendahuluan}

Diabetes Melitus (DM) adalah penyakit kronis progresif yang ditandai dengan ketidakmampuan tubuh untuk mealkukan metabolism karbohidrat, lemak dan protein, mengarah ke hiperglikemia atau disebut "Gula Tinggi".

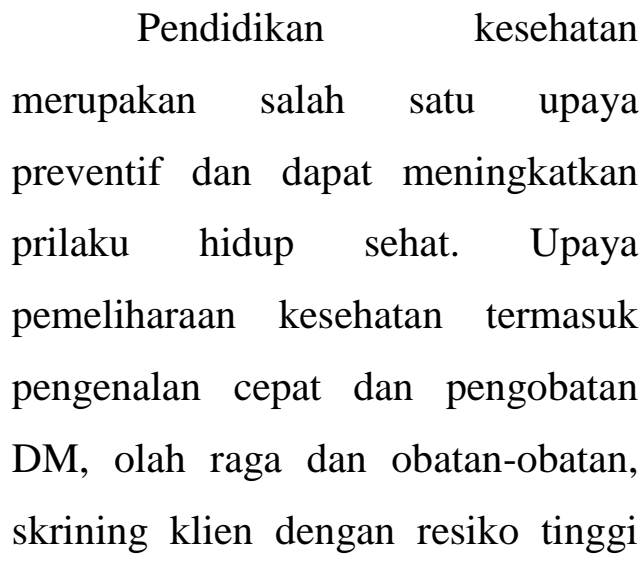

DM (Black dan Hawks, 2013). Keberhasilan pengelolaan diabetes mandiri membutuhkan partisipasi aktif klien, keluarga dan masyarakat (PERKENI, 2002).

\section{Pendidikan kesehatan}

dipengaruhi oleh beberapa faktor, faktor internal maupun eksternal penerima dan termasuk lingkungannya, pesan dapat tersampaikan dengan baik apabila antara penyampai pesan dan penerima pesan ada kebutuhan. Dan frekwensi pendidikan kesehatan dimungkinkan akan membantu pesan dapat tersampaikan. Dengan frekwensi pendidikan kesehatan yang berulang dimungkinkan penerima pesan memiliki motivasi dan keinginan yang lebih baik dari pada hanya dilakukan sekali saja. (Diabetes Australia, 1998).

Lansia merupakan proses aging yang normal dan dapat terjadi pada semua orang, lansia bukan penyakit tetapi dengan kondisi lansia dapat cepat menjadi sakit, oleh karena itu perlu mempersiapkan lansia dalam kondisi sehat sepanjang hidup pada masa yang dilaluinya.

Disamping merupakan kelompok rentang terhadap penyakit pada usia lansia harus tetap berada dalam kondisi kesehatan optimal. (Departemen Kesehtan RI, 2001). Pendidikan kesehatan pada lansia harus dilakukan berulang-ulang agar lebih menumbuhkan rasa percaya diri pada lansia.

Prilaku lansia dalam memeriksakan diri ke posyandu atau fasyankes dipengaruh oleh beberapa faktor. Banyak penelitian berkaitan dengan kepatuhan lansia datang ke posyandu, diantaranya pekerjaan, 
jarak posyandu dengan rumah lansia dan juga dukungan keluarga terhadap lansia merupakan faktor paling dominan (Pujiati, 2013).

\section{Diantara faktor-faktor}

tersebut masih terdapat faktor lain yang memungkinkan lansia berprilaku patuh untuk melakukan pemeriksaan/kontrol secara periodik ke posyandu, oleh karena itu peneliti mencoba salah satu faktor tersebut adalah seberapa sering lansia mendapat pendidikan kesehatan sehingga bersedia aktif datang ke posyandu. (Departemen Kesehtan RI, 2001).

Pemeriksaan kesehatan lansia yang dilakukan di wilayah Puskesmas Neglasari, terutama pada RT 01 dan RT 02 RW 04 Kelurahan Karang anyar Kecamatan Neglasari Kota Tangerang tahun 2013, didapatkan data sebagai berikut; terdapat 42 anggota keluarga berusia dalam rentang 45 - 60 tahun dan 12 orang berusia diatas 60 tahun dan terdapat 18 orang menderita hipertensi. dan ditemukan hasil pemeriksaan tekanan darah dan gula darah sewaktu rata-rata jumlah kasus dari setiap RW didapatkan hasil pemeriksaan gula darah diatas 170 ui dan tekanan darah rata-rata 150/90 mmHg.

$\begin{array}{ccc}\text { Kedua } & \text { hasil tersebut } \\ \text { mengambarkan } & \text { bahwa terdapat }\end{array}$
kecenderungan adanya faktor-faktor penyebab penyakit, diantaranya penyakit kardiovaskuler. Data-data tersebut diatas dan setelah mendapatkan fakta bahwa dari sejumlah 42 anggota yang memiliki lansia tidak ada satupun lansia melakukan kontrol/monitoring ke Puskesmas atau fasyankes lainnya tentang kesehatan dan terutama monitor gula darah, kolesterol darah dan asam urat darah.

Penelitian ini akan difokuskan pada wilayah Puskesmas Neglasari dan juga di wilayah RW 05 Kelurahan Karang anyar Kecamatan Neglasari Kota Tangerang, dengan tujuan penelitian mengidentifikasi pengaruh frekwensi pendidikan kesehatan terhadap prilaku kontrol/monitoring pemeriksaan kadargula darah pada lansia dengan penyakit atau memiliki riwayat DM. 


\section{Metode Penelitian}

Penelitian dilaksanakan dari bulan April sampai dengan bulan November 2015 dan pengambilan data dilakukan pada bulan Juni September 2015, di wilayah Puskesmas kecamatan Neglasari Kota Tangerang. Penelitian ini merupakan penelitian deskriptif korelasi dengan desain penelitian "Cross Sectional" dimana peneliti hanya ingin mengidentifikasi pengaruh frekwensi pendidikan kesehatan terhadap prilaku kontrol/monitoring kadar gula darah pada lansia dengan DM.

Populasi adalah Lansia yang memiliki riwayat DM yang berkunjung ke Puskesmas Kecamatan Neglasari dan posyandu lansia RW 05. Teknik pengambilan sampel yang digunakan adalah non probability convenience sample.

Setelah tempat penelitian ditentukan, maka langkah selanjutnya adalah pemilihan sampel dengan teknik consecutive sampling dimana semua subjek yang datang dan memenuhi kriteria pemilihan dimasukkan dalam penelitian sampai jumlah subjek yang diperlukan terpenuhi. Saat pengambilan data, peneliti bekerjasama dengan pihak puskesmas dalam menentukan kriteria inklusi.

Pasien yang datang ke pendaftaran untuk kontrol karena ada riwayat Diabetes Melitus langsung dijadikan responden. Pasien yang sudah diperiksa oleh dokter dan ternyata diketahui Diabetes Melitus juga masuk dalam kriteria inklusi sebagai responden. Jumlah pengumpulan data sehari tidak tentu karena disesuaikan dengan jumlah kunjungan ke Puskesmas yang ratarata banyak pada hari senin, selasa dan rabu. Dan untuk pengambilan sampel di wilayah RW 05 dilakukan dengan pemeriksaan kadar gula darah dan pendidikan kesehatan.

Kriteria inklusi Lansia dalam penelitian ini adalah: Bersedia menjadi responden dan kooperatif, bisa berjalan dan pendengaran tidak terganggu dan memiliki riwayat penyakit DM sedangkan kriteria eklusi dalam penelitian adalah: Terganggu pendengarannya, Tidak bisa berjalan dan tidak kooperatif. Instrumen yang digunakan dalam penelitian ini terdiri dari Kuesioner 
yang berisi data demografi responden dan pertanyaan penyakit penyerta/penyakit lain yang diderita lansia.

Adapun instrument penelitian adalah kuesioner yang seluruhnya terdiri dari 15 item pertanyaan utama, meliputi data demograsi atau karakteristik klien 9 item pertanyaan dan 3 pertanyaan yang berkaitan dengan riwayat penyakit lain, merokok, terapi obat dan tiga item pertanyaan berkaitan frekwensi pendidikan kesehatan.

Tehnik pengumpulan data yaitu dengan pengisian kusioner yang disi dengan cara wawancara dengan lansia, pengisian kuisioner dilakukan selama 15-20 menit, setelah semua terisi, selanjutnya peneliti/petugas memeriksa kembali jika ada pertanyaan yang belum diisi. Sedangkan analisis data melalui uji univariat dan bivariat dengan menggunakan chi square, dengan tingkat kepercayaan $95 \%$.

\section{Hasil}

$\begin{array}{lrr}\text { Hasil analisis univariat } \\ \text { menunjukkan rata-rata } & \text { umur } \\ \text { responden adalah } 57,55 & \text { tahun }\end{array}$

dengan usia termuda 45 tahun dan tertua 76 tahun. Hasil analisis univariat menunjukkan distribusi jenis kelamin responden didominasi oleh perempuan sebesar 73,3\%. Distribusi pekerjaan sebagian besar sebanyak 56,7\% sebagai Ibu rumah Tangga (IRT). Distribusi suku bangsa sebesar $65 \%$ adalah suku Betawi. Distribusi tingkat pendidikan sebagian besar sebanyak 73,3\% dengan pendidikan SD.

Hasil analisis univariat riwayat penyakit penyerta sebanyak $80 \%$ ada riwayat penyakit penyerta yang lain dan terdapat responden mempunyai riwayat penyakit stroke sebanyak $3,3 \%$.

Tabel 1.

Distribusi Frekuensi Responden Berdasarkan Frekuensi Pendidikan Kesehatan

\begin{tabular}{lcc}
\hline Frekuensi Penkes & F & \% \\
\hline 1-2 kali & 28 & 46,7 \\
3-4 kali & 32 & 53,3 \\
\hline Jumlah & 60 & 100 \\
\hline
\end{tabular}

Tabel 1 menunjukkan bahwa hampir sebagian $(46,7 \%)$ responden hanya mendapatkan $1-2$ kali pendidikan kesehatan terencana. 
Tabel 2

Distribusi Frekuensi Responden Berdasarkan Kontrol Gula Darah

\begin{tabular}{lll}
\hline Perilaku Kontrol & F & \% \\
\hline Tdk Pernah & 11 & 18,3 \\
Kadang-Kadang & 37 & 61,7 \\
Sering & 12 & 20,0 \\
\hline Jumlah & 60 & 100 \\
\hline
\end{tabular}

Tabel 2 menunjukkan bahwa sebagian besar $(80,0 \%)$ responden menyatakan tidak pernah dan

kadang-kadang saja dalam melakukan kontrol gula darah.

Pada hasil analisis bivariat menjelaskan mengenai hubungan antara frekuensi pendidikan kesehatan dengan perilaku kontrol kadar glukosa darah pada lansia penderita diabetes mellitus. analisis ini menggunakan analisis Chi Squere karena jenis data variabel dependen dan independen dalam bentuk kategorik. Adapun hasil dapat dibaca pada tabel 3, berikut ini :

Tabel 3

Analisis Hubungan Frekuensi Pendidikan Kesehatan dengan Perilaku Kontrol Kadar Glukosa Darah pada Lansia Penderita diabetes mellitus

\begin{tabular}{|c|c|c|c|c|c|c|c|c|c|}
\hline \multirow{3}{*}{$\begin{array}{l}\text { Frekuensi } \\
\text { Penkes }\end{array}$} & \multicolumn{6}{|c|}{ Perilaku Kontrol Glukosa Darah } & & & \multirow{3}{*}{ Nilai $\mathrm{p}$} \\
\hline & \multicolumn{2}{|c|}{ Tidak Kontrol } & \multicolumn{2}{|c|}{$\begin{array}{l}\text { Kadang- } \\
\text { Kadang }\end{array}$} & \multicolumn{2}{|c|}{ Sering } & \multicolumn{2}{|c|}{ Total } & \\
\hline & $\mathrm{F}$ & $\%$ & $\mathrm{~F}$ & $\%$ & $\mathrm{f}$ & $\%$ & $\mathrm{~F}$ & $\%$ & \\
\hline 1-2 kali & 5 & 17,9 & 23 & 82,1 & 0 & 0,0 & 28 & 100,0 & 0,001 \\
\hline 3-4 Kali & 6 & 18,8 & 14 & 43,8 & 12 & 35,0 & 32 & 100,0 & \\
\hline Jumlah & 11 & 18,3 & 37 & 61,7 & 12 & 20,0 & 60 & 100,0 & \\
\hline
\end{tabular}

Pada tabel 3; menunjukan bahwa dari 28 responden yang mendapatkan pendidikan kesehatan sebanyak 1-2 kali sebagian besar berperilaku kontrol kadar glukosa darah kadangkadang yaitu sebanyak 23 dari 28 orang $(82,1 \%)$ dan tidak ada yang periksa kadar glukosa darah kategori sering. Sedangkan responden yang mendapatkan pendidikan kesehatan
3-4 kali paling banyak berperilaku kontrol kadar glukosa darah dalam kategori kadang-kadang sebanyak 14 dari 32 orang $(43,8 \%)$, dan yang tidak pernah kontrol paling sedikit yaitu sebanyak 6 drai 32 orang $(18,8$ \%). Berdasarkan Hasil uji chi square pada nilai person chi-squere didapatkan ada hubungan yang siknifikan antara frekuensi 
pendidikan kesehatan dengan perilaku kontrol kadar glukosa darah pada lansia penderita diabetes millitus (DM), dengan nilai $\mathrm{P}=$ $0,001 \quad(\alpha=0,05)$. Hal ini berarti semakin banyak pendidikan pendidikan kesehatan yang diterima responden, maka semakin sering responden berperilaku kontrol kadar glukosa darah.

\section{Pembahasan}

Berdasarkan Riset Kesehatan Dasar (Riskesdas) nasional tahun 2007 prevalensi diabetes melitus pada penduduk berusia 18 tahun ke atas mencapai $28 \%$ dan terjadi penurunan $31,7 \%$ ditahun 2013 menjadi 25,3\% (Riskesdas, 2013), tetapi asumsi terjadi penurunan bisa bermacam-macam mulai dari alat ukur yang berbeda-beda atau masyarakat sudah berobat ke fasilitas pelayanan kesehatan (fasyankes), karena terjadi peningkatan prevalensi diabetes melitus (pada wawancara) dari 7,6\% tahun 2007 menjadi 9,5\% pada tahun 2013. Tanda dan gejala Lansia diabetes melitus seringkali tidak dirasakan sehingga Lansia tidak mendapat pengobatan yang sesuai, masalah diketahui setelah timbul komplikasi pada organ lain.

Berdasarkan hasil penelitian bahwa terdapat beberapa karakteristik yang dapat berpengaruh pada risiko dan tingkat keparahan terjadinya DM. Gejala DM tampak predominan pada usia lebih tua dari 40 tahun, dan 4-5 orang meninggal karena DM pada usia 65 tahun atau lebih.

Pada usia yang lebih tua, wanita mengalami serangan jantung dua kali lipat dari laki-laki dan meninggal karena bserangan jantung yang merupakan penyakit utama oleh sebab adanya riwayat DM (Black \& Hawks, 2009). Hasil penelitian ini sejalan dengan teori dimana distribusi usia responden berkisar 41 - 80 tahun, dimana pada usia tersebut fungsi tubuh sudah mulai mengalami penurunan sehingga akan lebih berisiko untuk mengalami DM dengan didukung riwayat DM yang sangat berhubungan dengan elastisitas pembuluh darah.

Hasil itu sejalan dimana perempuan dengan usia dewasa tua lebih banyak pekerjaan sebagai IRT didukung dengan tingkat pendidikan 
sebagian besar adalah SD. diminum tanpa melakukan kontrol Berdasarkan teori pada wanita yang sudah menopause lebih berisiko mengalami penyakit-penyakit kronis karena pengaruh dari hormon.

Walaupun pada awalnya lakilaki lebih risiko mengalami penyakit kronis. Hal ini juga dipengaruhi dari gaya hidup termasuk pola makan dan kebiasaan aktifitas sehari-hari dan olah raga. Hasil ini bisa didukung dari jenis kelamin perempuan, pekerjaan terbanyak sebagai IRT dengan rata-rata usia 61 tahun dan pendidikan SD, oleh karena itu gejala tidak terdeteksi dari awal, responden melakukan pengobatan ke puskesmas setelah ada gejala seperti sering sakit kepala, sakit sendi dan diketahui sudah DM.

Ada kemungkinan riwayat minum obat yang tidak teratur dan tidak ingat disebabkan karena pada saat obat akan habis tidak langsung datang berobat ke Puskesmas sehingga ada rentang waktu tidak minum obat. Dari respon yang disampaikan responden ada juga yang mengatakan bila tidak ada tanda dan gejala seringkali obat tidak tekanan darah secara teratur.

Hasil penelitian ini menegaskan bahwa adanya korelasi bahwa pendidikan kesehatan semakin banyak diberikan diharapkan adanya perubahan prilaku dari lansia terutama pada lansia yang mengalami penyakit seperti DM, hal penting dalam mengendalikan dan mengontrol DM, salah satunya adalah memonitor kadar gula darah klien (Blacks \& Hawks, 2014).

Hal ini juga sesuai dengan prinsip dari pendidikan kesehatan bila semakin banyak mendapatkan paparan pendidikan kesehatan terhadap sesuai yang dialaminya akan berpengaruh terhadap pola prilaku memanfaatkan fasyankes yang ada, walaupun banyak faktor yang menpengaruhi bahwa lansia kurang memanfaatkan fasyankes (Pujiati, 2013).

Dengan pendidikan serta pemanfaatan fasyankes diharapkan bahwa kontrol terhadap penyakit lansia semakin sering terlebih lagi bagi Lansia yang mengalami DM. 


\section{Simpulan}

Diabetes melitus yaitu penyakit metabolik yang ditandai dengan peningkatan kadar gula darah akibat gangguan pada sekresi insulin, kerja insulin atau keduanya. Penelitian ini menunjukan bahwa setengah responden mendapat pendidikan kesehatan terencana sebanyak 3-4 kali sejumlah 32 dari 60 orang (53,3 $\%$ ), dan sebagian besar responden berperilaku kontrol glukosa darah kadang-kadang yaitu sebanyak 37 dari 60 orang $(61,7 \%)$. Perilaku tidak pernah kontrol glukusa darah dan sering kontrol hampir seimbang yaitu $18,3 \%$ dan $20 \%$. Hal ini menunjukkan pentingnya monitoring kadar gula darah terutama bagi penderita penyakit diabetes melitus. Pendidikan kesehatan kepada Lansia dan keluarga yang difokuskan pada upaya promotif dan preventif, khususnya dalam memodifikasi gaya hidup. Hasil penelitian ini menunjukan bahwa ada hubungan yang siknifikan antara frekuensi pendidikan kesehatan dengan perilaku kontrol kadar glukosa darah pada lansia penderita diabetes millitus, dengan nilai $\mathrm{P}=0,001$ $(\alpha=0,05)$. Hal ini berarti semakin banyak pendidikan pendidikan kesehatan yang diterima responden, maka semakin sering responden berperilaku kontrol/monitoring kadar glukosa darah.

\section{Daftar Pustaka}

Black, J.M. \& Hawks, J.H. (2014). Medical Surgical Nursing : Clinical Management for Positive Outcomes. Eight Edition. Volume 2. USA : Saunders Elsevier.

Diabetes Australia, (1998). Diabetes management in general practice, Fifth Edition; Canberra: National Capital Printing

$\begin{array}{cr}\text { Pengurus Besar } & \text { Perkumpulan } \\ \text { Endokrinologi } & \text { Indonesia } \\ \text { (PB.PERKENI), } & \text { (2002). } \\ \text { Konsesnsus pengelolaan diabetes } \\ \text { Melitus Tipe 2 di Indonesia 2002. } \\ \text { Jakarta: PB. PERKENI }\end{array}$

Pujiati dkk. 2013. Dukungan keluarga mempengaruhi usia lanjut datang ke posyandu, Jurnal Keperawatan. Volume 2/Nomor1 Mei 2013

Departeen Kesehatan RI. (2001). Pedoman pembi naan kesehatan usia lanjut bagi petugas kesehatan, Jilid I. Jakarta: Direktorat Bina Kesehatan keluarga Departemen Kesehatan RI. 
Lemeshow, S., Hosmer, D.W., Klar, J. \& Lwanga, S.K. (1997). Besar Sampel Dalam Penelitian Kesehatan. Yogyakarta Universitas Gajah Mada Press.

Kementerian Kesehatan RI, (2013). Riset Kesehatan dasar (Riskesdas) Tahun 2013, Kemenkes RI, Jakarta. 